\title{
The December 2018 Anak Krakatau Volcano Tsunami as Inferred from Post-Tsunami Field Surveys and Spectral Analysis
}

\author{
Abdul Muhari, ${ }^{1}$ (D Mohammad Heidarzadeh, ${ }^{2}$ Harjo Susmoro, ${ }^{3}$ Haris D. Nugroho, ${ }^{3}$ Estu Kriswati, ${ }^{4}$ \\ Supartoyo, ${ }^{4}$ Antonius B. Wijanarto, ${ }^{5}$ Fumihiko Imamura, ${ }^{6}$ and Taro Arikawa ${ }^{7}$
}

\begin{abstract}
We present analysis of the December 2018 Anak Krakatau tsunami in Sunda Strait, Indonesia, from a combination of post-tsunami field surveys, bathymetric changes and spectral analysis of the tsunami tide gauge records. Post-tsunami surveys revealed moderate tsunami height along the coast of Sumatra and Java with maximum surveyed runup of $13.5 \mathrm{~m}$ and maximum inundation distance of $330 \mathrm{~m}$. At small islands located close to the volcano, extreme tsunami impacts were observed indicating not only a huge tsunami was generated by large amounts of collapse material which caused notable changes of seafloor bathymetry, but also indicates the role of those small islands in reducing tsunami height that propagated to the mainland of Indonesia. Our spectral analysis of tide gauge records showed that the tsunami's dominant period was 6.6-7.4 min, indicating the short-period nature of the 2018 Sunda Strait tsunami.
\end{abstract}

Keywords: Sunda strait tsunami, anak Krakatau Volcano, post-tsunami survey.

Electronic supplementary material The online version of this article (https://doi.org/10.1007/s00024-019-02358-2) contains supplementary material, which is available to authorized users.

1 National Disaster Management Authority of Indonesia, Jakarta, Indonesia. E-mail: abdul.muhari@gmail.com

2 Department of Civil and Environmental Engineering, Brunel University London, Uxbridge UB8 3PH, UK. E-mail: mohammad.heidarzadeh@brunel.ac.uk

3 Naval Hydrographic and Oceanographic Center, Jakarta, Indonesia. E-mail: kapushidrosal@pushidrosal.id

4 Geological Agency of Indonesia, Bandung, Indonesia. E-mail: estu.kriswati@esdm.go.id; supartoyo@gmail.com

5 Indonesian Spatial Agency, Jakarta, Indonesia. E-mail: ab.wijanarto@gmail.com

6 International Research Institute of Disasters Science, Tohoku University, Sendai, Japan. E-mail: imamura@irides.tohoku.ac.jp

7 Chuo University, Tokyo, Japan. E-mail: taro.arikawa.38d@u-chuo.ac.jp

\section{Introduction}

A series of eruptions of the Anak Krakatau (AK) volcano in Sunda Strait, Indonesia (Fig. 1), from 22 to 26 December 2018 generated a large tsunami on 22 December 2018 which killed 437 people (BNPBNational Disaster Management Authority 2019). Since the existing tsunami warning in Indonesia was designed for earthquake-induced tsunamis, the system did not warn coastal communities at risk. This deadly tsunami occurred approximately 2 months after another destructive tsunami in Sulawesi, east Indonesia, with approximately 2000 deaths (Muhari et al. 2018; Heidarzadeh et al. 2018b; Omira et al. 2019). To date, the generation mechanism of the December 2018 AK tsunami is still unclear as to whether it was generated by a single large caldera collapse or by retrogressive failures, because the seismic station at the AK volcano was offline since 21:03 local time, presumably because of damage due to the eruption. Based on the seismic tremors recorded at other stations, tectonic tremors of the 22 December 2018 AK eruption were recorded at 20:55 local time (UTC + 7) at RSAM seismic station in Sertung Island (Fig. S1), located $3 \mathrm{~km}$ westward of the AK volcano, and at other stations in Java and Sumatra (Figs. 1 and S1). Therefore, we identified the origin time of the tsunamigenic volcanic activity as 20:55 local time (13:55 UTC, Fig. S1).

Tsunamis generated by volcanic activities, including those from landslide processes or due to earthquake-induced mass failures, historically could have involved large amount of collapse materials, such as the 2002 Stromboli flank collapse that involved $17 \times 10^{6} \mathrm{~m}^{3}$ volume of materials (Maramai 
(a) Sunda Strait tsunami, 22 Dec 2018

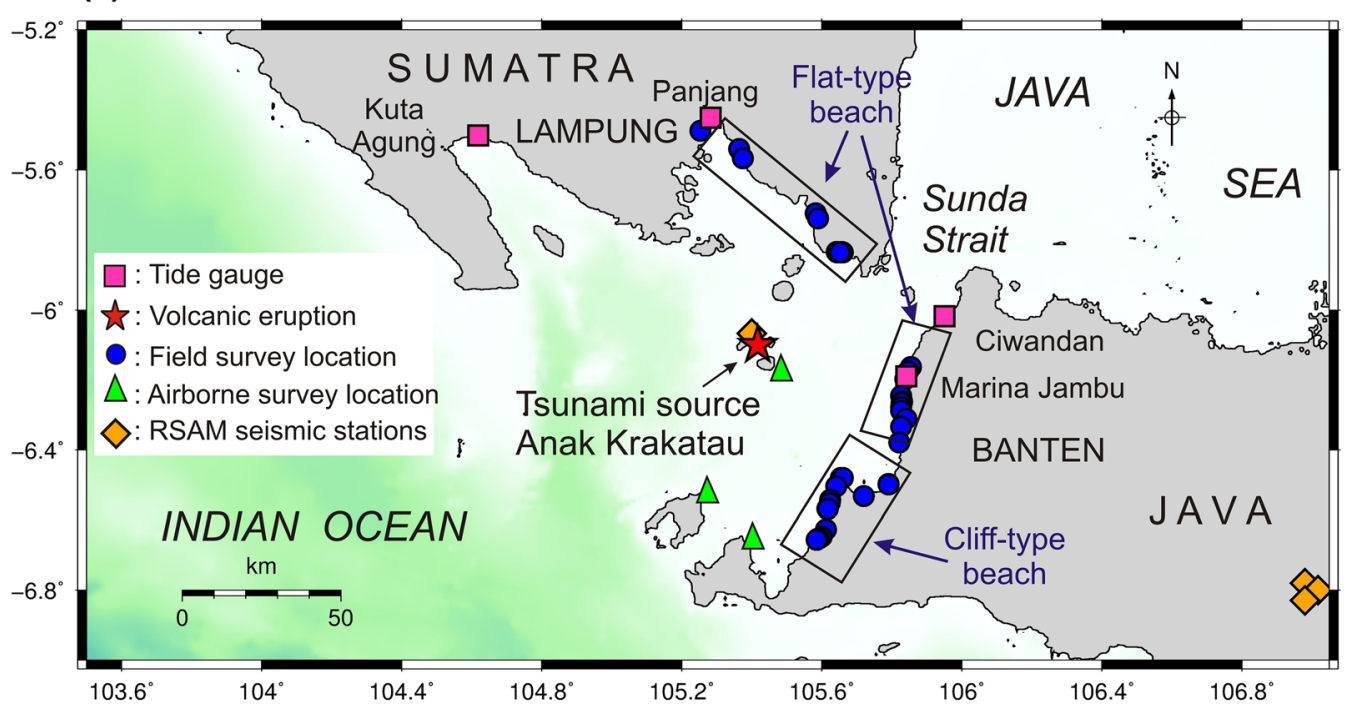

(b) Original records

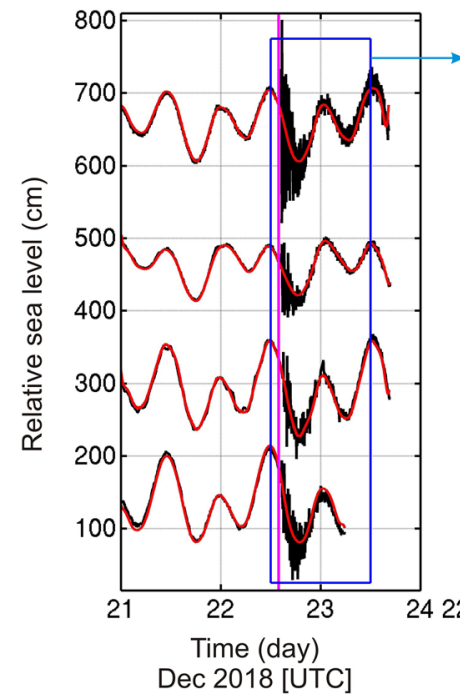

(c) De-tided waveforms

(d) De-tided waveforms
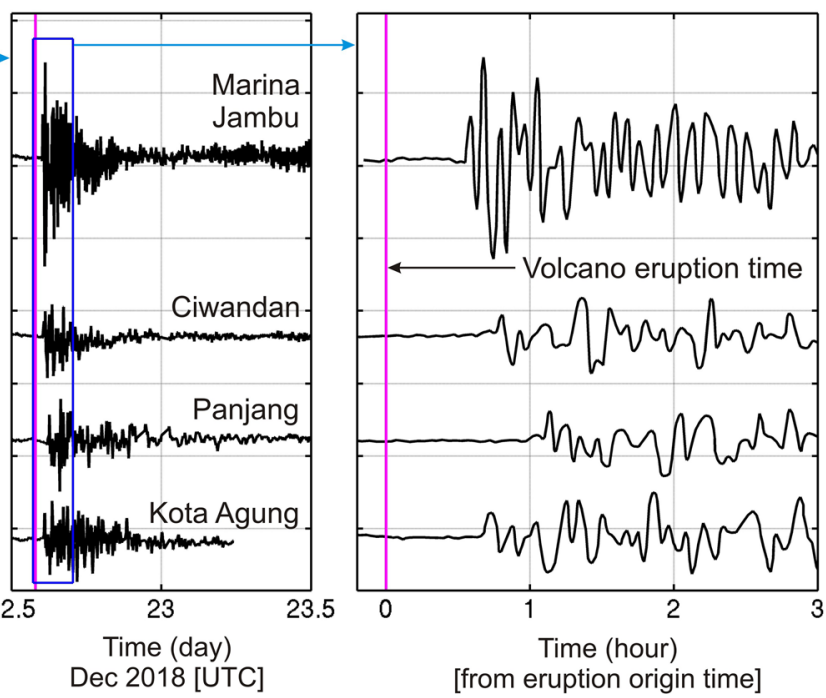

Figure 1

a Locations of the Anak Krakatau volcanic eruption and tsunami on 22 December 2018, the coastal post-tsunami survey points and the tide gauges. b Original tide gauge records (black) and tide prediction (red). c, d De-tided tsunami waveforms. Origin time of the volcanic eruption is assumed to be 22 December 2018 at 13:55:00 UTC (pink vertical line)

et al. 2005) and the 1958 Lituya Bay event with $30 \times 10^{6} \mathrm{~m}^{3}$ of sliding mass (Fritz et al. 2001). The December 2018 AK volcano tsunami is expected to have also involved large amount of material capable of generating a tsunami, which affected areas up to $120 \mathrm{~km}$ distance from the source and produced large coastal runup heights at the nearby areas (e.g. Heidarzadeh et al. 2019).
In this research, we first describe results of posttsunami field surveys which were conducted 4 days after the tsunami. The survey team measured tsunami runup heights and flow depths in two regions; the first is in the southern part of Lampung Province at Sumatra Island and the second area is along the west coast of Banten Province at Java Island (Fig. 1). Surveyed areas at Lampung Province extended 
approximately $55 \mathrm{~km}$ from $5.48^{\circ} \mathrm{S}$, documenting tsunami traces southward till $5.83^{\circ} \mathrm{S}$. In Banten Province, the surveyed area stretched about $75 \mathrm{~km}$ southward from 6.17 to $6.65^{\circ} \mathrm{S}$.

Since approaching the AK volcano was prohibited in the first few weeks after the eruptions, a series of airborne surveys were conducted from 27 December 2018 to 7 January 2019 to provide the first visualization of the aftermath by using ultra high-resolution GPS cameras. To complete the analysis, we present a comparison of pre- and post-event bathymetry data surrounding the AK volcano. This allows identifying notable bathymetric changes after the eruptions. Furthermore, we perform spectral analysis of the tsunami waveforms from four tide gauges around the Sunda Strait to infer the physical properties of the tsunami.

\section{Tsunami Field Surveys}

The post-tsunami survey team measured tsunami parameters at 64 coastal points in Lampung and Banten from 26 to 30 December 2018. Tsunami flow depth was measured from ground level at locations where reliable tsunami traces were found. Tsunami runup was measured by using automatic laser rangefinders referenced to the IOC post-tsunami survey guideline (UNESCO 2014). The surveyed runup heights were later adjusted to account for the tidal levels at the time of the tsunami event.

Beach morphology at the surveyed areas consists of two different types (see boxes in Fig. 1): the first type includes the surveyed areas in Lampung and the northern part of Banten coast in the latitude range of $6.17^{\circ} \mathrm{S}-6.49^{\circ} \mathrm{S}$. These areas are characterized by flat topography, where the beach slope is less than $10^{\circ}$ and the difference between ground elevation and mean sea level is usually less than $5 \mathrm{~m}$ within the distance of $100 \mathrm{~m}$ from the coast. Geologically, these areas were composed of loose sand with gray-white to brownish color and quaternary coral limestone at some area with grain size of moderate to coarse sand. The second type is the cliff-type beaches at the southern part of Banten in $6.50^{\circ} \mathrm{S}-6.65^{\circ} \mathrm{S}$, where ground levels $>10 \mathrm{~m}$ (from sea level) can be found in a relatively shorter distance from the coast.
Moderate to high relief characterizes this type of coast, composed of tertiary volcanic rock including lava, volcanic breccia and tuff.

\subsection{Tsunami Runups and Flow Depths}

In Lampung Province, tsunami traces were measured at 15 points where flow depth reached $2.9 \mathrm{~m}$ and maximum tsunami inundation distance was up to $150 \mathrm{~m}$ at Kunjir Village, Rajabasa Subdistrict (Fig. 2). Measurements in Lampung were mostly made in Rajabasa Subdistrict since tsunami traces were less visible in other places. In this region, the average tsunami flow depth was $1.5 \mathrm{~m}$ and it inundated coastal areas as far as $50 \mathrm{~m}$ from the coast, on the average (Tables 1, 2).

In Banten coast (east to southeast side of the AK volcano), different levels of tsunami inundation depths and runups were observed. Coastal locations from $6.1^{\circ} \mathrm{S}$ to the north suffered less tsunami destruction, where small wooden stores located very close to the shoreline survived without any significant damage (Fig. 3a). Tsunami traces were not visible in this location, and condition of grasses and sands did not indicate that a tsunami inundated the area. However, the Ciwandan tide gauge station, located in this region, recorded maximum tsunami amplitude of $0.5 \mathrm{~m}$ arriving $46 \mathrm{~min}$ after the first tsunami peak (Table 3). In addition to the fact that the tsunami that arrived in this area was not significant, fewer tsunami traces available here may be attributed to the existence of coastal defense structures which were built to protect the seaside parts of resorts and villas. Such protecting structures must have prevented the tsunami from overflowing and penetrating further inland (Fig. 3b).

Moving southward to the latitude range of $6.17^{\circ} \mathrm{S}-6.37^{\circ} \mathrm{S}$, the average flow depth, runup and inundation distance were $2.2 \mathrm{~m}, 4.4 \mathrm{~m}$ and $131.2 \mathrm{~m}$, respectively. Here, tsunami traces were clearly observed at the walls of the damaged buildings located close to the shore. Maximum runup was $5.8 \mathrm{~m}$ (location $6.20^{\circ} \mathrm{S}, 105.84^{\circ} \mathrm{E}$ ) and maximum inundation distance was up to $330 \mathrm{~m}$ (location $\left.6.26^{\circ} \mathrm{S}, 105.83^{\circ} \mathrm{E}\right)$. Longer inundation distances observed here could be attributed to the higher flow depths, in addition to flat topography which helped 


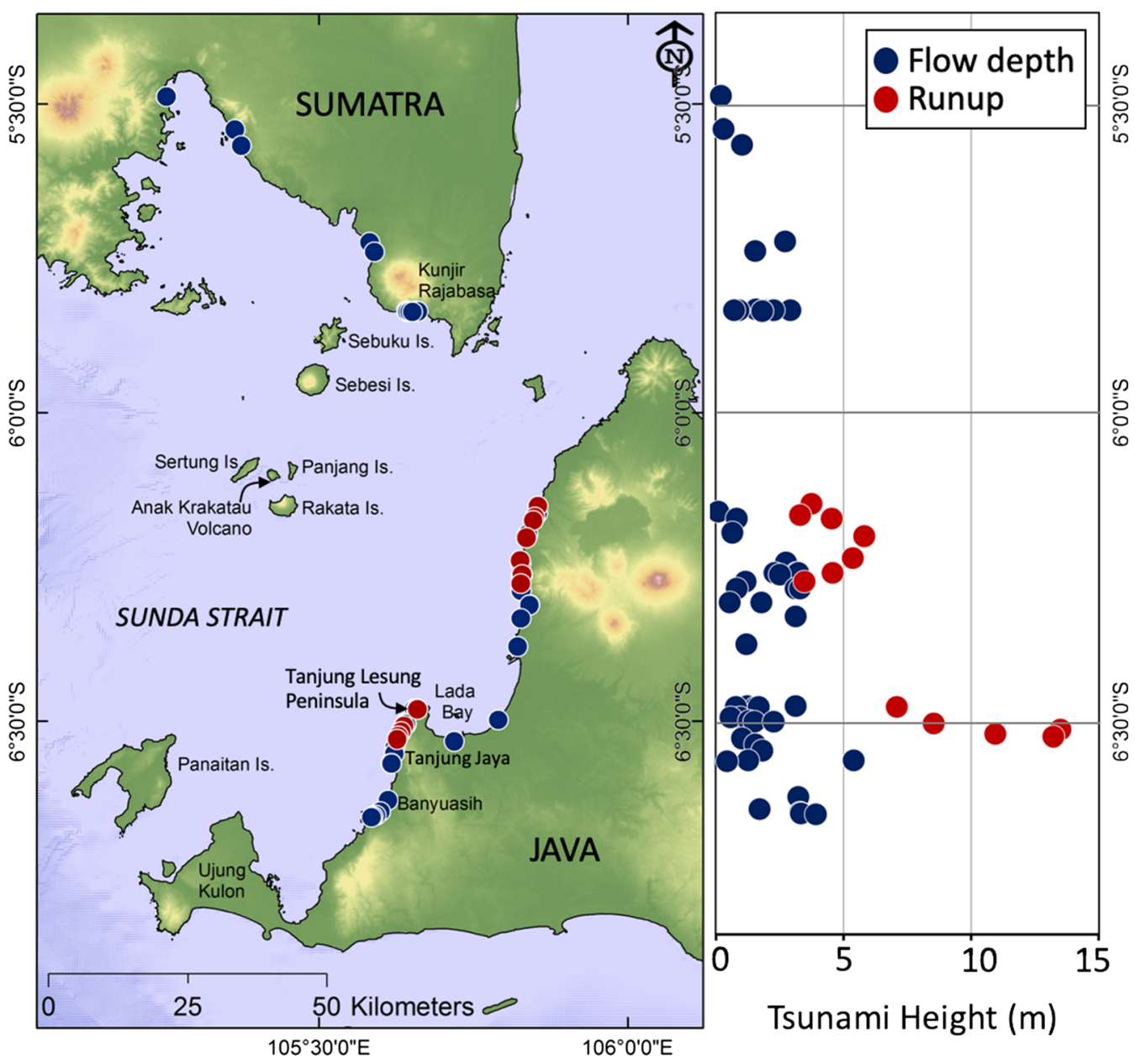

Figure 2

Distribution of the measured tsunami flow depth (blue) and runup (red) in Sumatra and Java coasts due to the December 2018 Anak Krakatau tsunami in Sunda Strait, Indonesia

the tsunami to penetrate further inland once it overtopped the coastal structures.

Towards the south at a narrow bay named Lada Bay located at $6.4^{\circ} \mathrm{S}-6.53^{\circ} \mathrm{S}$ and $105.68^{\circ} \mathrm{E}-105.82^{\circ} \mathrm{E}$ (see location in Fig. 2), almost no tsunami trace was observed, although such a narrow bay has the potential to amplify tsunami heights. One reason that the area inside the bay was less affected by the tsunami is the fact that the bay is relatively sheltered by Tanjung Lesung peninsula, a most attractive tourism destination in the region, which was itself heavily damaged by the tsunami with at least 52 casualties. At the time of the tsunami, the Tanjung Lesung peninsula resort area was packed with visitors for the end-of-the-year festivals.
At the cliff-type beach areas, tsunami energy is converted more into runup height rather than inundation distance (Kakinuma et al. 2012). In Tanjung Jaya and Banyuasih subdistrict, the area with clifftype beaches located at the latitude range of $6.48^{\circ} \mathrm{S}-$ $6.55^{\circ} \mathrm{S}$, a larger tsunami was observed with a maximum runup of $13.5 \mathrm{~m}$, maximum flow depth of $5.4 \mathrm{~m}$ and inundation distance of up to $159 \mathrm{~m}$. Most of the beach areas were completely swept away and coastal forest was heavily damaged (Fig. 4a). Coral boulders were drifted up to $100 \mathrm{~m}$ to inland with sizes of up to as big as a medium truck (Fig. 4b) indicating the extreme powers of the tsunami flows. 
Table 1

Tsunami flow depth measurements at various locations due to the December 2018 Anak Krakatau volcano tsunami in the Sunda Strait, Indonesia

\begin{tabular}{|c|c|c|c|}
\hline No & $X$ & $Y$ & Flow depth (m) \\
\hline 1 & 105.25324 & -5.48743 & 0.20 \\
\hline 2 & 105.36367 & -5.54036 & 0.30 \\
\hline 3 & 105.37437 & -5.56649 & 1.00 \\
\hline 4 & 105.58218 & -5.72368 & 2.70 \\
\hline 5 & 105.58982 & -5.73918 & 1.54 \\
\hline 6 & 105.64236 & -5.83479 & 1.55 \\
\hline 7 & 105.65678 & -5.83513 & 2.90 \\
\hline 8 & 105.65993 & -5.83560 & 0.89 \\
\hline 9 & 105.65320 & -5.83575 & 2.14 \\
\hline 10 & 105.66005 & -5.83580 & 0.87 \\
\hline 11 & 105.66004 & -5.83584 & 0.70 \\
\hline 12 & 105.64394 & -5.83594 & 1.86 \\
\hline 13 & 105.64731 & -5.83615 & 2.24 \\
\hline 14 & 105.65143 & -5.83652 & 1.80 \\
\hline 15 & 105.65143 & -5.83652 & 1.80 \\
\hline 16 & 105.85435 & -6.16275 & 0.10 \\
\hline 17 & 105.84697 & -6.17453 & 0.81 \\
\hline 18 & 105.83830 & -6.19698 & 0.63 \\
\hline 19 & 105.82696 & -6.24482 & 2.75 \\
\hline 20 & 105.82892 & -6.26183 & 3.15 \\
\hline 21 & 105.82887 & -6.26210 & 3.20 \\
\hline 22 & 105.82924 & -6.26258 & 2.30 \\
\hline 23 & 105.82810 & -6.26492 & 2.50 \\
\hline 24 & 105.82700 & -6.27700 & 1.14 \\
\hline 25 & 105.82674 & -6.28779 & 3.10 \\
\hline 26 & 105.82695 & -6.28814 & 3.30 \\
\hline 27 & 105.82718 & -6.28863 & 0.80 \\
\hline 28 & 105.84152 & -6.31085 & 0.54 \\
\hline 29 & 105.84093 & -6.31130 & 1.76 \\
\hline 30 & 105.82707 & -6.33320 & 3.10 \\
\hline 31 & 105.82153 & -6.37886 & 1.20 \\
\hline 32 & 105.65817 & -6.47995 & 1.23 \\
\hline 33 & 105.65940 & -6.48005 & 3.10 \\
\hline 34 & 105.65436 & -6.48011 & 1.55 \\
\hline 35 & 105.65817 & -6.48033 & 0.77 \\
\hline 36 & 105.65935 & -6.48047 & 1.65 \\
\hline 37 & 105.79015 & -6.49799 & 0.96 \\
\hline 38 & 105.79039 & -6.49821 & 0.56 \\
\hline 39 & 105.64078 & -6.50363 & 1.30 \\
\hline 40 & 105.64165 & -6.50461 & 1.51 \\
\hline 41 & 105.64101 & -6.50466 & 2.24 \\
\hline 42 & 105.71942 & -6.53244 & 1.00 \\
\hline 43 & 105.62356 & -6.54209 & 1.54 \\
\hline 44 & 105.62223 & -6.55211 & 1.82 \\
\hline 45 & 105.61664 & -6.56774 & 5.40 \\
\hline 46 & 105.61785 & -6.56787 & 1.25 \\
\hline 47 & 105.61800 & -6.56839 & 0.43 \\
\hline 48 & 105.61205 & -6.62732 & 3.20 \\
\hline 49 & 105.59950 & -6.64651 & 1.70 \\
\hline 50 & 105.59235 & -6.65183 & 3.28 \\
\hline 51 & 105.58749 & -6.65393 & 3.33 \\
\hline 52 & 105.58537 & -6.65560 & 3.90 \\
\hline
\end{tabular}

Table 2

Tsunami runup measurements at various locations due to the December 2018 Anak Krakatau volcano tsunami in the Sunda Strait, Indonesia

\begin{tabular}{llll}
\hline No & $X$ & $Y$ & Runup (m) \\
\hline 1 & 105.85470 & -6.15110 & 3.74 \\
2 & 105.84969 & -6.16902 & 3.29 \\
3 & 105.84747 & -6.17476 & 4.54 \\
4 & 105.83619 & -6.20232 & 5.8 \\
5 & 105.82577 & -6.23888 & 5.34 \\
6 & 105.82887 & -6.26210 & 4.57 \\
7 & 105.82698 & -6.27677 & 3.45 \\
8 & 105.65939 & -6.48078 & 7.07 \\
9 & 105.63815 & -6.50781 & 8.51 \\
10 & 105.63335 & -6.51699 & 13.49 \\
11 & 105.62888 & -6.52415 & 10.94 \\
12 & 105.62673 & -6.52896 & 13.2 \\
\hline
\end{tabular}

\subsection{Tsunami Impacts from Airborne Survey}

At the islands surrounding the AK volcano, tsunami impacts are visible from the damage of coastal forests. At Sertung Island, dense vegetation at the northern part disappeared and only a tree was left at the sand spit of about $200 \mathrm{~m}$ length (Fig. 5a). At the southern part of the island, we observed the creation of an immense outcrop with height of up to $40 \mathrm{~m}$ after the tsunami impact (Fig. 5b). However, this outcrop might have been generated by mechanisms other than the direct tsunami impacts because of its symmetric shape and also because of the absence of tree debris on its top boundary. This may favour the hypothesis of material sliding, which could have been tsunamigenic. Loss of vegetation is also visible at the inner side of Rakata Island, with an estimated height of up to $15 \mathrm{~m}$ above sea level (Fig. 5c).

Further tsunami impacts were observed in the natural area designated for the conservation of rhinoceros at the Ujung Kulon Peninsula located approximately $60 \mathrm{~km}$ south of the AK volcano. Tsunami severely impacted the $4.5-\mathrm{km}$ stretch coastline where the coastal forest was completely swept away to a distance of up to $800 \mathrm{~m}$ inland (Fig. 6a). Similar damage is also seen on an island located in the north of Ujung Kulon called Panaitan Island. Here, coastal forest located on the northwest of the peninsula was shattered by the tsunami, which 

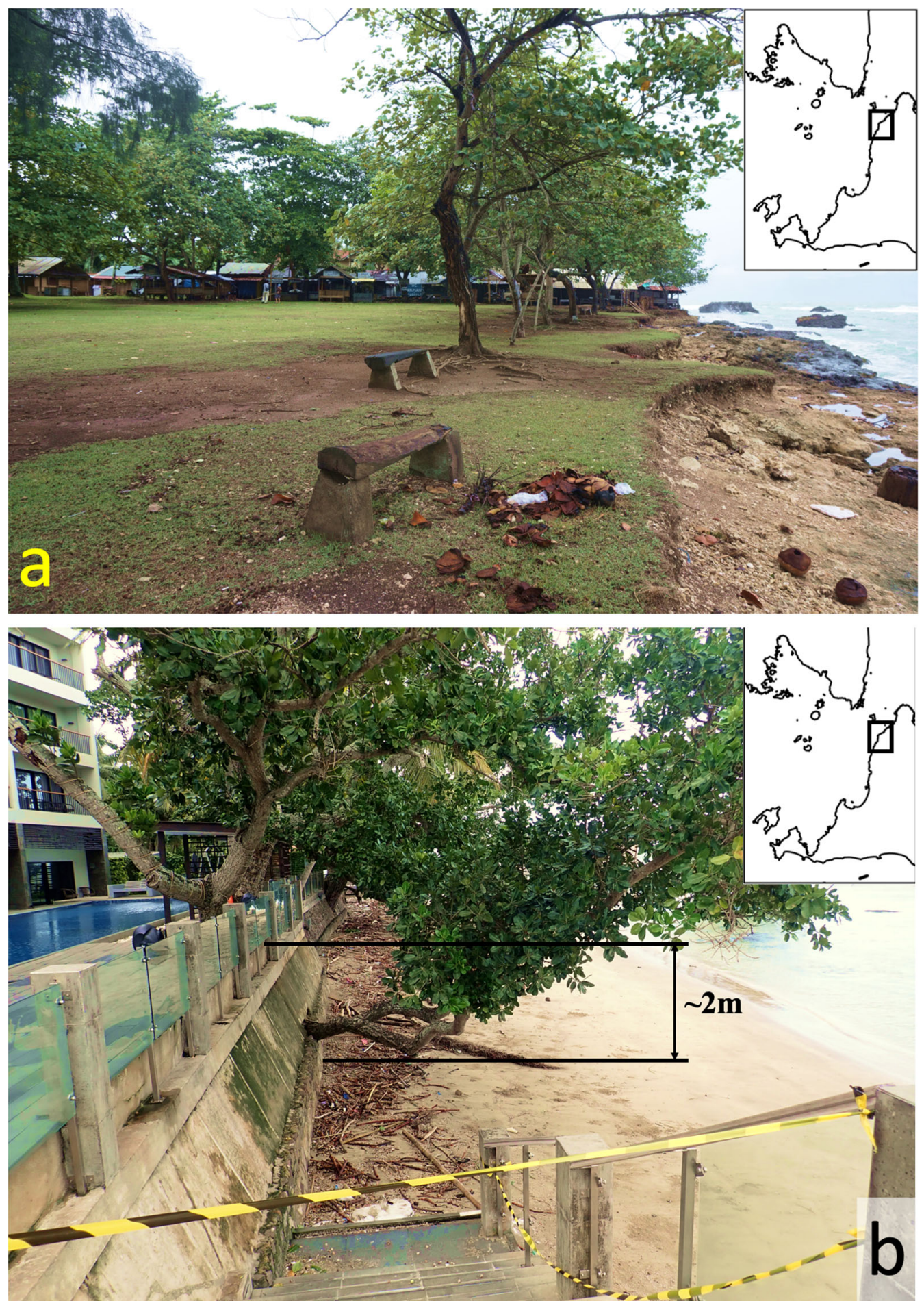

Figure 3

a A tourism site at the northern part of Banten where small wooden stores survive from the tsunami, b Coastal structure that was built integrated with the sea side part of hotels and villas that prevented the tsunami from penetrating inland 
Table 3

Physical properties of the tsunami waves resulting from the 22 December 2018 Anak Krakatau volcano eruption

\begin{tabular}{|c|c|c|c|c|c|c|}
\hline \multirow[t]{2}{*}{ Station } & \multicolumn{3}{|c|}{ First tsunami wave } & \multicolumn{2}{|c|}{ Maximum tsunami waves } & \multirow{2}{*}{$\begin{array}{l}\text { Duration high-energy } \\
\text { waves }(\mathrm{h})\end{array}$} \\
\hline & $\begin{array}{l}\text { Arrival time } \\
\text { (UTC) }\end{array}$ & $\begin{array}{l}\text { Travel time } \\
(\mathrm{min})\end{array}$ & $\begin{array}{l}\text { Amplitude }(\mathrm{cm}) \\
\text { sign* }\end{array}$ & $\begin{array}{l}\text { Time (UTC) of } \max \\
\text { amplitude }\end{array}$ & $\begin{array}{l}\text { Max amplitude } \\
(\mathrm{cm})\end{array}$ & \\
\hline $\begin{array}{l}\text { Marina } \\
\text { Jambu }\end{array}$ & $14: 28$ & 33 & +59.3 & $14: 36$ & 139.3 & 7.0 \\
\hline Ciwandan & $14: 30$ & 35 & +25 & $15: 16$ & 51.2 & 6.0 \\
\hline $\begin{array}{l}\text { Kota } \\
\text { Agung }\end{array}$ & $14: 36$ & 41 & +30.9 & $15: 46$ & 62.4 & 6.0 \\
\hline Panjang & $14: 52$ & 57 & +36.6 & $16: 43$ & 43.5 & 8.5 \\
\hline
\end{tabular}

Origin time of the volcanic eruption is assumed to be 22 December 2018 at 13:55:00 UTC

*Plus and minus signs represent first elevation or depression waves, respectively

washed away trees and vegetation to a distance of $200 \mathrm{~m}$ inland (Fig. 6b). These two locations are uninhabited and the vegetation in this area is at least 100 years old. Therefore, the tsunami that attacked these areas should have been higher than the one that hit Lampung and Banten coasts in mainland Indonesia.

Although most of the coastal forests observed through the airborne and land-based post-tsunami surveys were damaged by the tsunami, the case in Banyuasih Village (located at $6.57^{\circ} \mathrm{S}$ and $105.62^{\circ} \mathrm{E}$ ) showed the protective role of vegetation in reducing tsunami forces for tsunamis of less than $5 \mathrm{~m}$ in height. Here, a tsunami flow depth of $3.6 \mathrm{~m}$ at the coast was reduced to $0.4 \mathrm{~m}$ due to the protective effect of a 200-m thick coastal forest (Fig. 6c).

\subsection{Bathymetric Data}

The Naval Hydrographic and Oceanographic Center of Indonesia (http://www.pushidrosal.id) conducted a rapid bathymetric survey from 25 to 30 December 2019 by using multibeam sonar equipment in response to the AK volcano eruption (PUSHIDROSAL-Naval Hydrographic and Oceanographic Center 2019). Previously, they conducted a bathymetric survey by using similar equipment at the surrounding AK volcano in 2016 (PUSHIDROSALNaval Hydrographic and Oceanographic Center 2016). Having those time series data allowed the comparison between the bathymetric data before and after the eruption. Since the mechanism of caldera collapse is unclear, analysis of bathymetric changes can only draw upon the volume of materials involved during the caldera collapse, regardless of the mechanism. The surveyed area of the new bathymetry, however, covered only a portion of the area in front of the horseshoe caldera opening because approaching the AK volcano during the survey period was not allowed due to the eruption activities (Fig. 7).

In order to reveal the notable bathymetric changes through making cross-sections of the bathymetric data, we extracted the bathymetric data of the 2016 and 2018 surveys along the cross-section line a'-b' in Fig. 7 (see the 2016 and 2018 survey traces in Figs. S2-S4). This cross-section line has water depths of $150 \mathrm{~m}$ in the north and $255 \mathrm{~m}$ in the south based on the 2016 bathymetric data. By analyzing the posteruption bathymetry data, we observed an increase in the seafloor elevation towards south, indicating that the collapse material spread out not only to the west (as indicated by the visible horseshoe caldera opening of the AK) but also to the south part of the AK volcano (Fig. 7).

\section{Tide Gauge Data and Spectral Analysis}

We obtained and processed four tide gauge records from the Indonesian Spatial Agency (http:// tides.big.go.id) with $1 \mathrm{~min}$ sampling interval at Marina Jambu, Ciwandan, Panjang and Kota Agung (see Fig. 1 for locations and waveforms). Tidal signals were estimated by applying the TIDALFIT tidal 

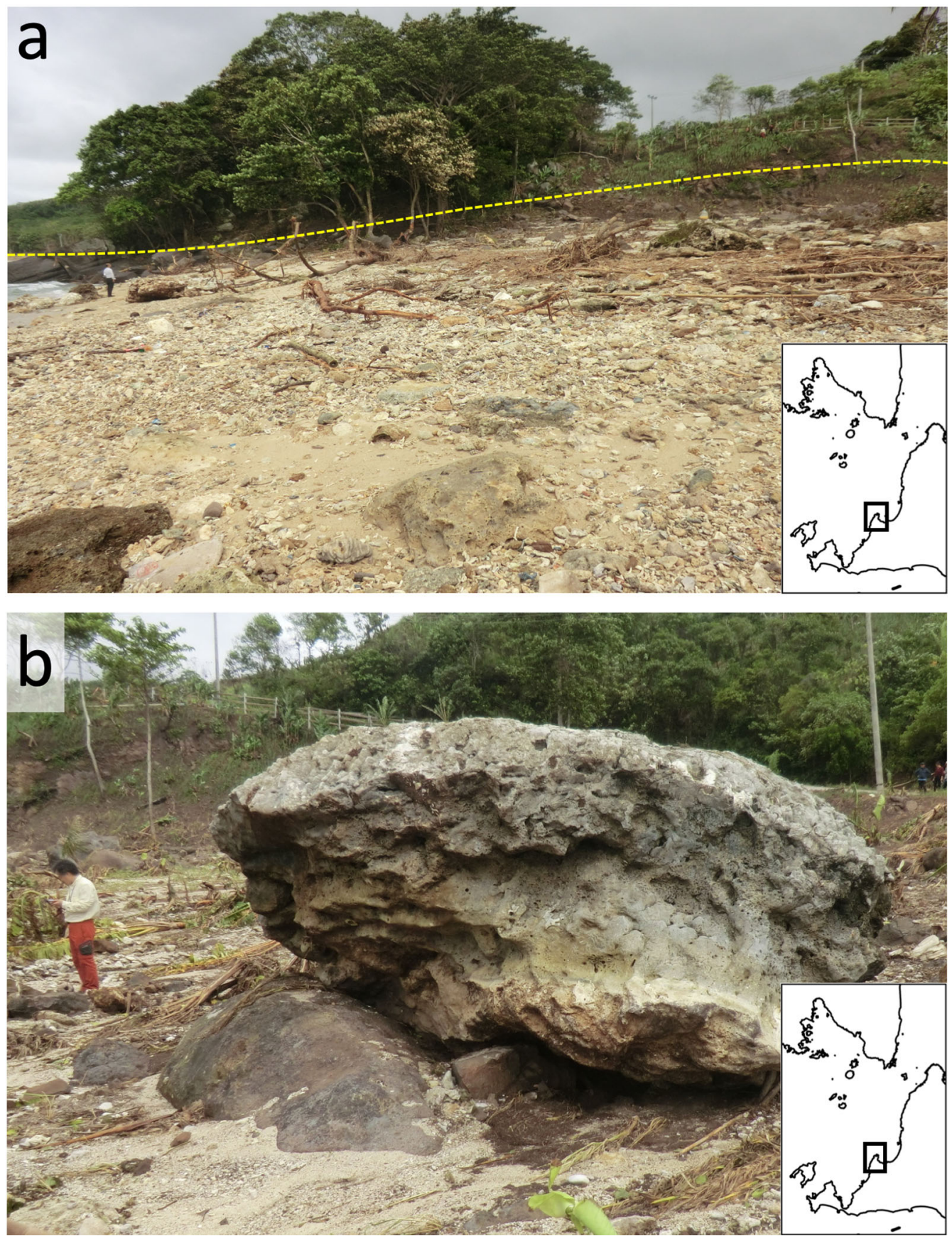

Figure 4

a The surveyed inundation line in a cliff beach area located at Tanjung Jaya Village, (b) A drifted coral boulder at a distance of $100 \mathrm{~m}$ inland from the shoreline at Tanjung Jaya Village

analysis package (Grinsted 2008; Heidarzadeh et al. 2018a); the original sea level records were removed to obtain de-tided waveforms. We used an origin time of 13:55 UTC to be consistent with the seismic record
(Fig. S1) to calculate travel times of the first and the largest tsunami waves in our de-tided waveforms. To estimate the duration of high-energy tsunami waves at each station, the Averaged Room-Mean Squares 

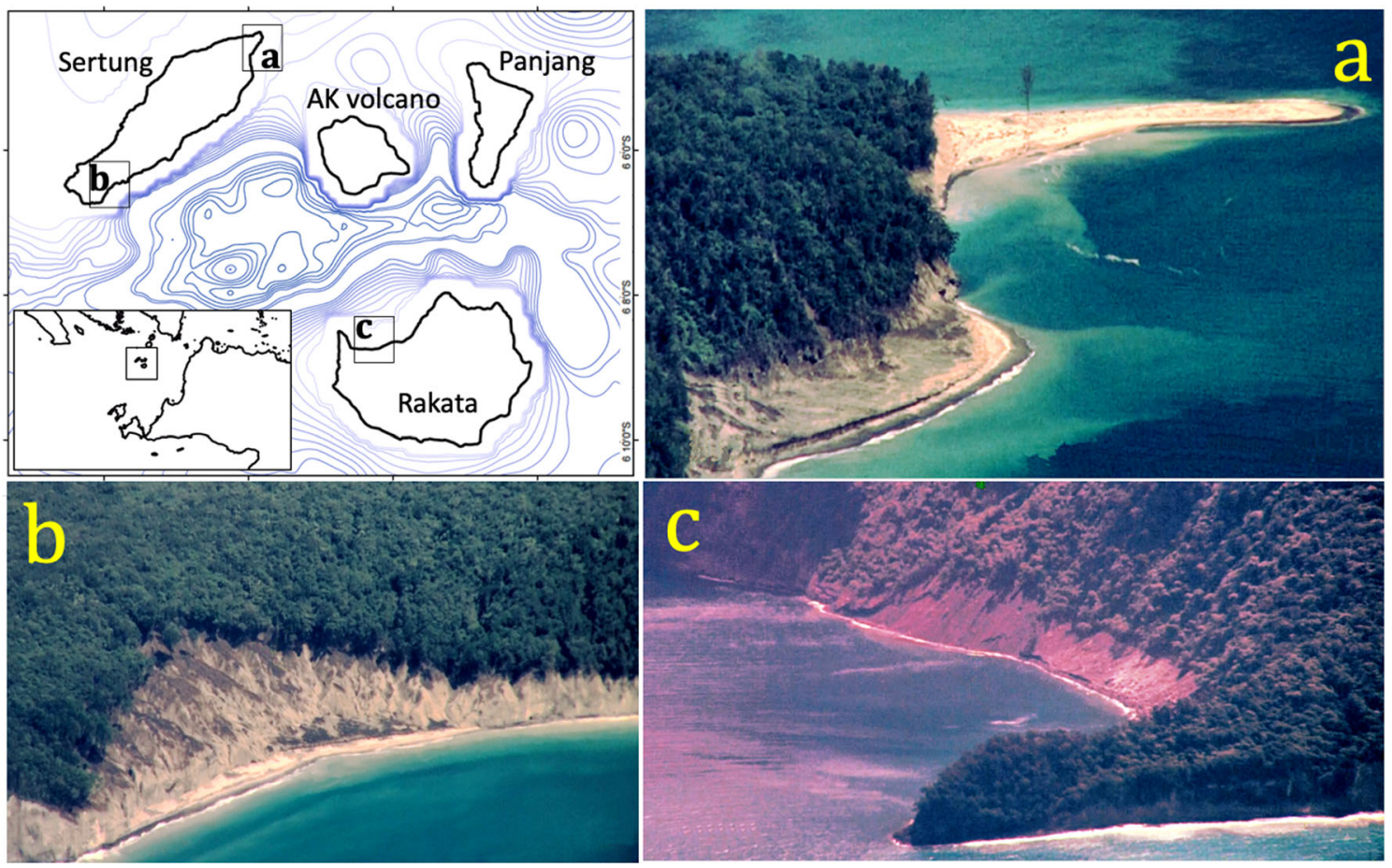

Figure 5

Tsunami impacts in islands surrounding AK Volcano referring to figure in the upper left, (a) Destruction at the north part of Sertung Island, (b) Outcrop at the south part of Sertung Island and (c) Damage to vegetation at Rakata Island

(ARMS) of the waveforms were calculated and a moving time window with length of 20 min (i.e., 20 data points) was applied while calculating the ARMS of the waveforms (Heidarzadeh and Satake 2014; Heidarzadeh et al. 2018b). Spectral analysis was conducted following the Welch algorithm (Welch 1967) using half-window overlaps as previously discussed by Rabinovich (2010) and Heidarzadeh et al. (2016). A Hanning window length of 60 min (60 data points) was considered for spectral analysis, thus the overlap was $30 \mathrm{~min}$. The peaks of the spectral plots are considered to be the dominant periods of the tsunami (Rabinovich et al. 2008, 2017; Heidarzadeh et al. 2015b).

\section{Discussions}

\subsection{Tsunami and Coastal Forest}

In order to qualitatively estimate tsunami characteristics within the airborne surveyed area, we first discuss the correlation between tsunami height and its corresponding damage to coastal forest. Shuto (1987) reported that trees would start to break down due to wave forces when tsunami height exceeds $4 \mathrm{~m}$. If tsunami height exceeds $8 \mathrm{~m}$, there will be no reduction effect from coastal forest at all. From physical modeling experiments, Harada and Imamura (2005) showed that a 100-m width of a coastal forest has the ability to reduce hydraulic forces of a tsunami up to $70 \%$ for the case of a $<3-\mathrm{m}$ tsunami. Furthermore, particular physical parameters of tree,s such as trunk height and width, were found to control the impacts of the 2011 tsunami in Japan such as lodging, uprooting and breaking (Matsutomi et al. 2012). Individual trees with trunk width of up to $0.8 \mathrm{~m}$ could resist a tsunami with height of up to $10 \mathrm{~m}$ according to Matsutomi et al. (2012).

Based on the above, reduction of tsunami height up to $88 \%$ at the southern part of the Banten coast (which has saved wooden and masonry residential buildings from a 3.6-m tsunami, Fig. 5) seems to be 

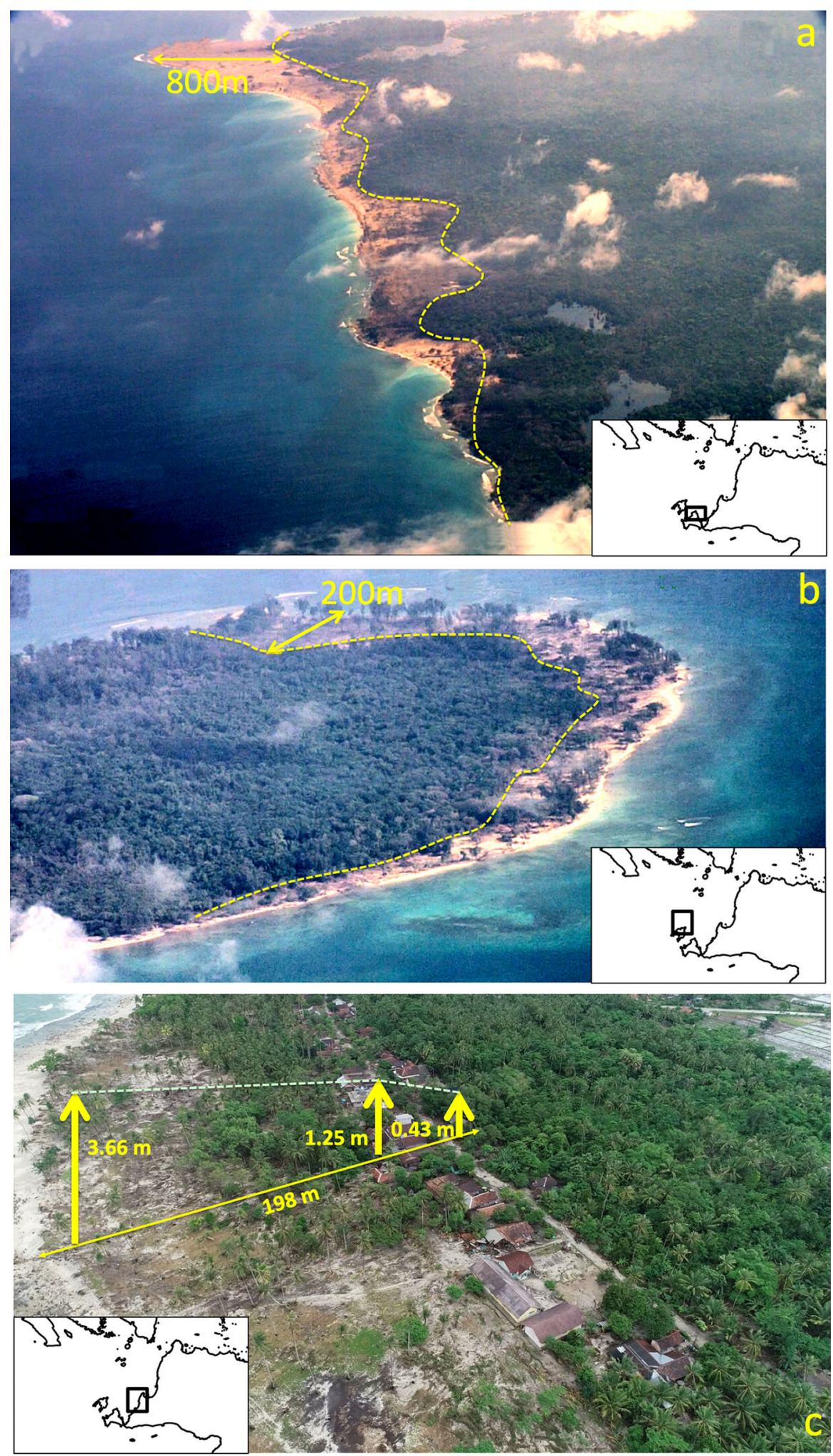
Figure 6

a Observed damage at Ujung Kulon Peninsula where tsunami penetrated and destroyed dense vegetation up to $800 \mathrm{~m}$ inland at the tip of the peninsula. b Damages in Panaitan Island located at the north of Ujung Kulon Peninsula. c Effect of coastal forest in reducing tsunami impact (less than $5 \mathrm{~m}$ height tsunami) to residential areas (6.570070 S: 105.617438 E) during the December 2018 Anak Krakatau tsunami consistent with general condition of the role of coastal forest in mitigating tsunami impacts (Shuto 1987; Harada and Imamura 2005; Matsutomi et al. 2012). At other areas, complete damage of the coastal forest at the islands surrounding the AK volcano, Panaitan and the northern part of Ujung Kulon Peninsula indicates that tsunami heights most likely exceeded the thresholds introduced by Shuto (1987), Harada and Imamura (2005), and Matsutomi et al.

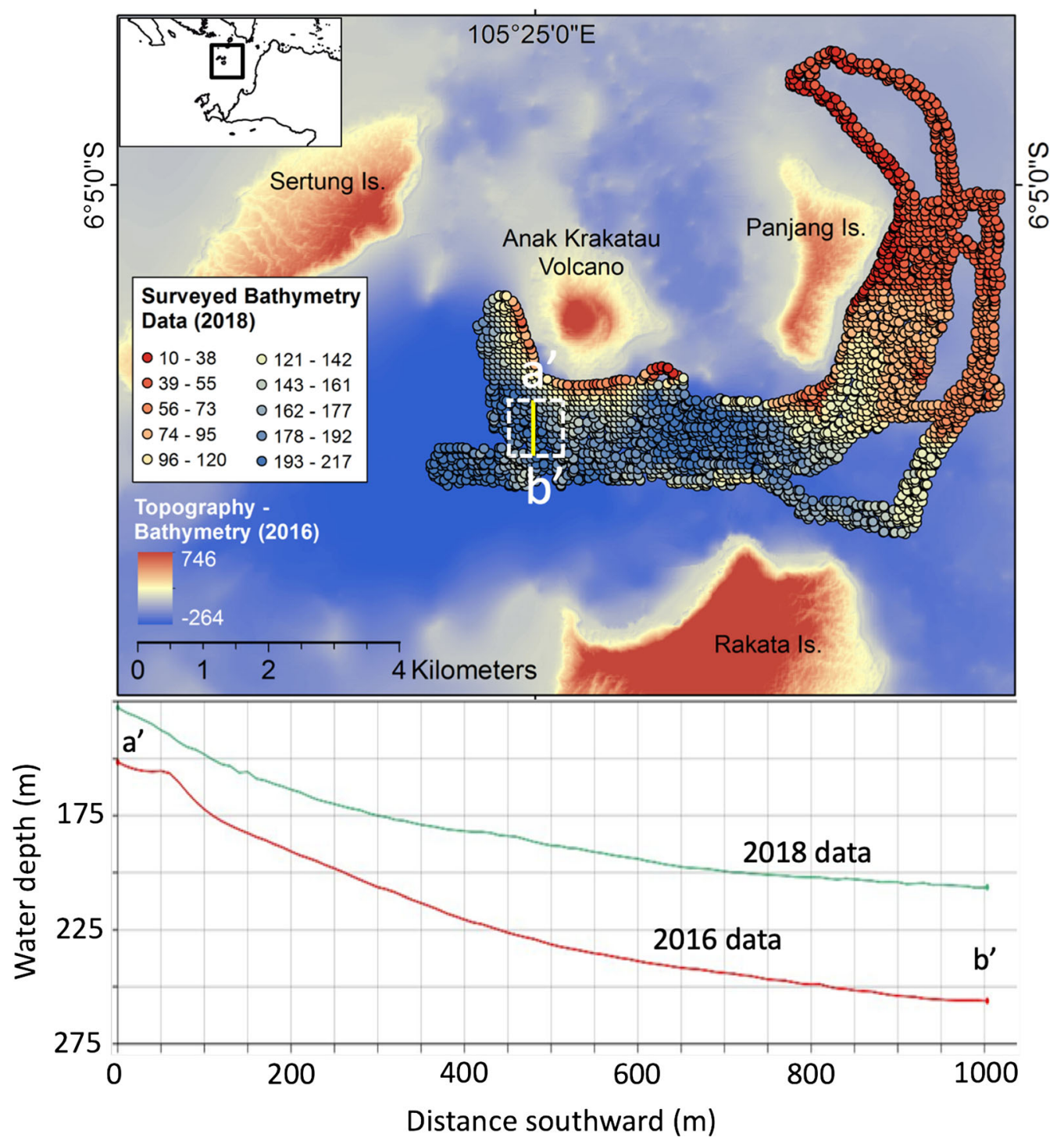

Figure 7

Newly surveyed bathymetry data after the December 2018 Anak Krakatau tsunami in Sunda Strait, Indonesia (colored dots in upper panel). Lower panel is the comparison between the 2016 and 2018 (post-tsunami) bathymetry data along the cross section line a'-b' shown in the upper panel, which is located at the south of the Anak Krakatau Island 
(a) Original records

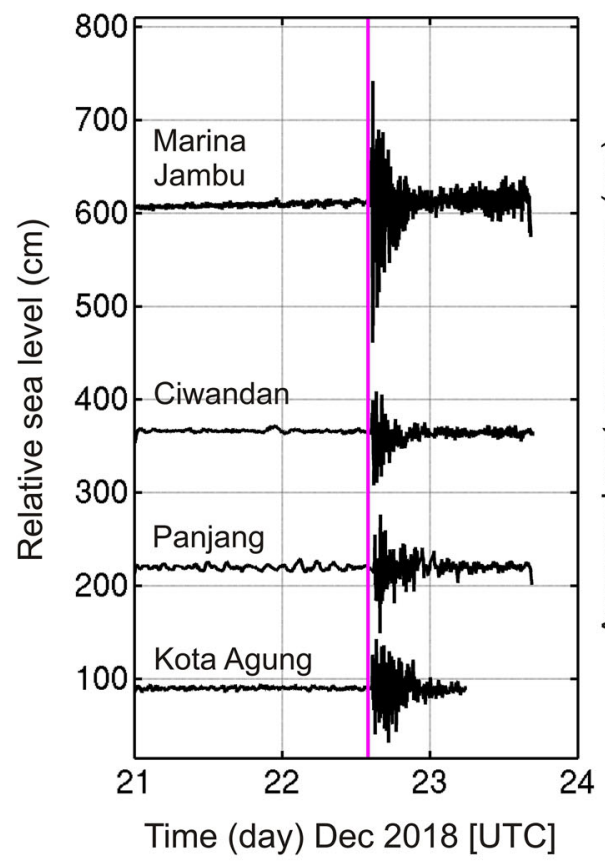

(c) Spectra (b) ARMS of the tsunami amplitudes

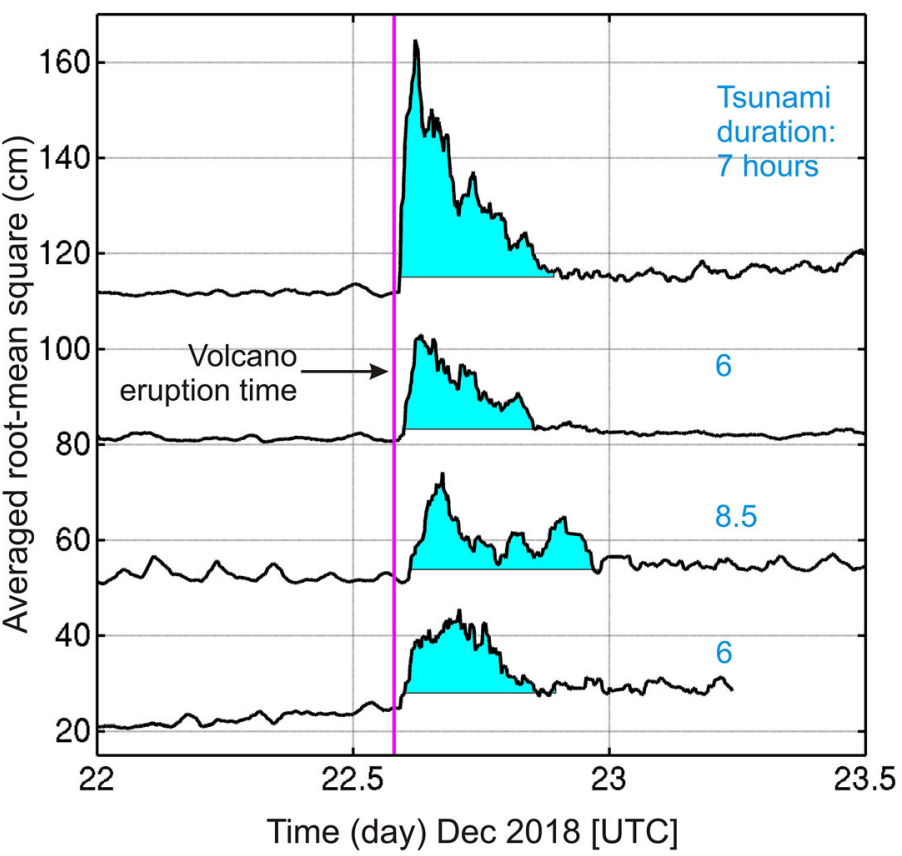

Tsunami period $(\mathrm{min})$

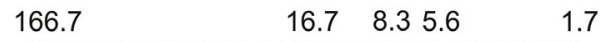
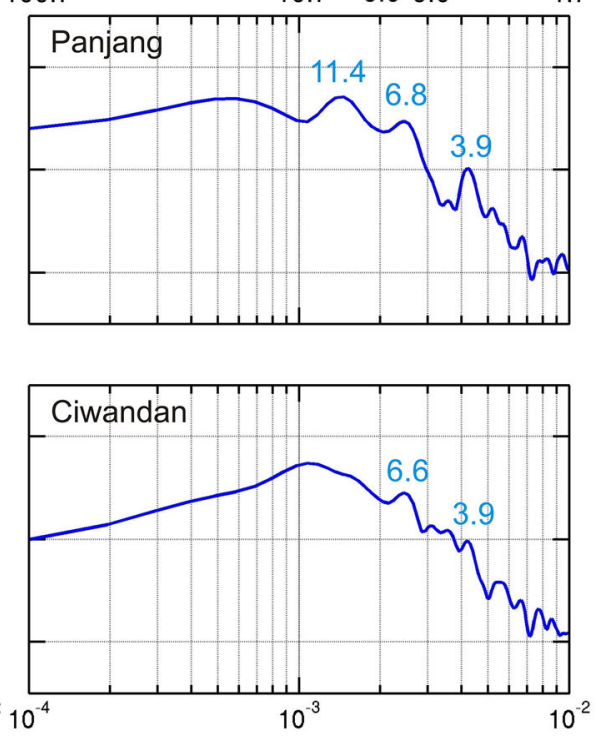

Tsunami frequency $(1 / \mathrm{s})$

Figure 8

a De-tided tsunami waveforms of the tsunami waves resulting from the 22 December 2018 Anak Krakatau volcano eruption. b The averaged root-mean square (ARMS) of the tsunami amplitude. The blue-shaded faces show the tsunami wave duration in each station. Origin time of the volcanic eruption is assumed to be 22 December 2018 at 13:55:00 UTC. The blue numbers show tsunami durations (in hours) at different stations. c Results of spectral analysis. The numbers within the spectral plots show dominant tsunami periods 
(2012). Such extremely large damage on coastal forests was seen only during the 2011 Japan tsunami. We, therefore, assume that the tsunami runup exceeded $10 \mathrm{~m}$ in height in those areas.

\subsection{Tsunami Waveforms and Spectral Analysis}

We show the de-tided waveforms at four tidal stations in Fig. 7. All four stations registered clear tsunami waves, which allowed us to determine physical properties of the tsunami (Table 3). Tsunami travel times were in the range of 33-57 min for the four stations. The amplitudes of the first elevation waves varied from $25 \mathrm{~cm}$ in Ciwandan to $59.3 \mathrm{~cm}$ in Marina Jambu, while the largest tsunami waves in the same stations were 51.2 and $139.3 \mathrm{~cm}$, respectively. Table 3 also reveals that the largest tsunami waves arrived from a few minutes to a few hours after the first arrival. In Marina Jambu, the largest wave arrived $8 \mathrm{~min}$ after the first arrival, whereas it arrived 111 min after the first arrival in Panjang. The duration of high-energy tsunami waves was $6-8.5 \mathrm{~h}$ in various stations (shaded faces in Fig. 8, Table 3), which is relatively short in comparison to general tectonically-induced tsunamis, which usually last from one to several days (Heidarzadeh et al. 2017; Heidarzadeh and Satake 2014). The short duration of tsunami from AK volcano eruption can be possibly attributed to the short-period waves generated by the eruption-related mechanism in comparison to longerperiod waves generated by earthquake fault ruptures.

Figure 8 gives the spectra of the AK volcano tsunami waves. Different peak periods are seen in the spectra of various stations including: 11.4, 10.0, 7.4, $6.8,6.6,5.3,3.9$ and $3.8 \mathrm{~min}$. These spectral plots may indicate that the tsunami period band was 3.8-11.4 min. According to Rabinovich (1997), the dominant tsunami period is the period that repeats in various stations. Using this criterion, we may report that the dominant period of the 2018 Krakatoa tsunami was $6.6-7.4 \mathrm{~min}$.

By using the obtained tsunami dominant period and considering the average water depth around the source region ( $\sim 40-80 \mathrm{~m}$ ), we estimate the tsunami source length using the equation of Heidarzadeh and Satake (2015), which gives a source length of $3.9-6.2 \mathrm{~km}$. It should be added that the tsunami period registered at tide gauges is the same as that in the source area because tsunami period remains the same along the journey from the source area to tide gauges. We note that this value is the dimension of the initial water surface disturbance at the beginning of the tsunami propagation; it is not the size of the volcano material. Experience shows that the size of the sliding mass is usually smaller than the size of the water surface at the end of the generation phase.

\section{Conclusions}

The 22 December 2018 AK volcano tsunami was studied through field surveys, spectral analysis and bathymetric data analysis. Local morphology distinguishes moderate tsunami runups at flat coastal areas from those high runups at cliff-type beaches. The maximum inundation distance was measured as $330 \mathrm{~m}$ in the flat coastal areas, and the maximum runup was found to be $13.5 \mathrm{~m}$ at the cliff-type beach in the south of Banten. Extreme damage at small islands close to the $\mathrm{AK}$ volcano indicates that those islands might have reduced tsunami amplitudes before they arrived at the coasts of Banten and Lampung in mainland Indonesia. While the detailed tsunami generation mechanism is still unknowneither mass sliding or in a block-fall manner, one go or in a progressive sequence-the result of bathymetric data analysis prior to and after the eruption shows a notable change in the canyon that was created after the 1883 eruption, where sediments more than $50 \mathrm{~m}$ thick were found after the 2018 AK volcano tsunami. Tsunami waveform analysis revealed that the December 2018 volcanic tsunami was a short-period and short-duration tsunami, with dominant period and duration of 6.6-7.4 min and 6-8.5 h, respectively. These numbers are significantly shorter than those from usual tectonic tsunamis.

\section{Acknowledgements}

Authors are grateful to the Minister of Marine Affairs and Fisheries, Susi Pudjiastuti and Director General of Marine Spatial Management, Brahmantya Satyamurti Poerwadi for their supports from the early 
stages of the study. The authors also thank the Chairwoman of National Agency of Meteorology, Climatology and Geophysics of Indonesia, Prof. Dwikorita Karnawati for involving AM in the airborne survey. This research is partially funded by International Research Institute of Disaster Science, Tohoku University, Japan. Survey team member from Ministry of Marine Affairs and Fisheries; Bobby Arianto, Oktanul Dinata. Survey team from Geological Agency of Indonesia is acknowledged. $\mathrm{MH}$ is funded by the Royal Society (grant number CHL\R1\180173) and the Brunel University London (Brunel Research Initiative and Enterprise Fund 2017/18, BUL BRIEF).

Open Access This article is distributed under the terms of the Creative Commons Attribution 4.0 International License (http:// creativecommons.org/licenses/by/4.0/), which permits unrestricted use, distribution, and reproduction in any medium, provided you give appropriate credit to the original author(s) and the source, provide a link to the Creative Commons license, and indicate if changes were made.

Publisher's Note Springer Nature remains neutral with regard to jurisdictional claims in published maps and institutional affiliations.

\section{REFERENCES}

BNPB-National Disaster Management Agency. (2019). Tsunami Selat Sunda. (https://bnpb.go.id/publikasi/infografis/tsunamiselat-sunda.html. Last Accessed on 8 March 2019).

Fritz, H. M., Hager, W. H., \& Minor, H. E. (2001). Lituya Bay case: rockslide impact and wave runup. Science of Tsunami Hazards, 19, 3-22.

Grinsted, A. (2008). Tidal Fitting Toolbox. https://uk.mathworks. com/matlabcentral/fileexchange/19099-tidal-fittingtoolbox? focused $=3854016 \&$ tab $=$ function\&s_tid $=$ gn_loc drop). Accessed on 29 March 2018

Harada, K., \& Imamura, F. (2005). Effects of coastal forest on tsunami hazard mitigation-a preliminary investigation. In $\mathrm{K}$. Satake (Ed.), Tsunamis. Advances in natural and technological hazards research (Vol. 23). Dordrecht: Springer.

Heidarzadeh, M., Harada, T., Satake, K., Ishibe, T., \& Gusman, A. (2016). Comparative study of two tsunamigenic earthquakes in the Solomon Islands: $2015 \mathrm{Mw} 7.0$ normal-fault and 2013 Santa Cruz Mw 8.0 megathrust earthquakes. Geophysical Research Letters, 43(9), 4340-4349.

Heidarzadeh, M., Muhari, A., \& Wijanarto, A. B. (2018a). Insights on the source of the 28 September 2018 Sulawesi tsunami, Indonesia based on spectral analyses and numerical simulations.
Pure and Applied Geophysics, 176(1), 25-34. https://doi.org/10. 1007/s00024-018-2065-9.

Heidarzadeh, M., Necmioglu, O., Ishibe, T., \& Yalciner, A. C. (2017). Bodrum-Kos (Turkey-Greece) Mw 6.6 earthquake and tsunami of 20 July 2017: a test for the Mediterranean tsunami warning system. Geoscience Letters, 4, 31. https://doi.org/10. 1186/s40562-017-0097-0.

Heidarzadeh, M., \& Satake, K. (2014). Excitation of basin-wide modes of the Pacific Ocean following the March 2011 Tohoku tsunami. Pure Appl Geophys, 171(12), 3405-3419.

Heidarzadeh, M., \& Satake, K. (2015). New insights into the source of the makran tsunami of 27 November 1945 from Tsunami waveforms and coastal deformation data. Pure Appl Geophys, 172(3), 621-640.

Heidarzadeh, M., Satake, K., Murotani, S., Gusman, A. R., \& Watada, S. (2015). Deep-water characteristics of the trans-Pacific tsunami from the 1 April $2014 \mathrm{M}$ w 8.2 Iquique, Chile Earthquake. Pure Appl Geophy, 172(3-4), 719-730.

Heidarzadeh, M., Teeuw, R., Day, S., \& Solana, C. (2018b). Storm wave runups and sea level variations for the September 2017 Hurricane Maria along the coast of Dominica, eastern Caribbean Sea: evidence from field surveys and sea level data analysis. Coastal Engineering Journal, 60(3), 371-384. https://doi.org/10. 1080/21664250.2018.1546269.

Heidarzadeh, M., Ishibe, T., Sandanbata, O., Muhari, A., Wijanarto, A.B. (2019). Numerical modeling of the subaerial landslide source of the 22 December 2018 Anak Krakatoa volcanic tsunami, Indonesia. Ocean Engineering. https://doi.org/10. 1016/j.oceaneng.2019.106733.

Kakinuma, T., Tsujimoto, G., Yasuda, T., \& Tamada, T. (2012). Trace survey results of the 2011 Tohoku earthquake tsunami in the north of Miyagi Prefecture and numerical simulation of bidirectional tsunamis in Utatsusaki peninsula. Coastal Engineering Journal, 54(1), 1250007.

Maramai, A., Graziani, L., Alessio, G., Burrato, P., Colini, L., Nappi, R., et al. (2005). Near- and farfield survey report of the 30 December 2002 Stromboli (Southern Italy) tsunami. Marine Geology, 215, 93-106.

Matsutomi, H., Yamaguchi, E., Naoe, K., \& Harada, K. (2012). Damage to reinforced concrete buildings and coastal trees due to the 2011 off the Pacific coast of Tohoku earthquake tsunami. Coastal Engineering Proceedings, 33, 1848-1860. https://doi. org/10.9753/icce.v33.management.51.

Muhari, A., Imamura, F., Arikawa, T., Hakim, A., \& Afriyanto, B. (2018). Solving the Puzzle of the September 2018 Palu, Indonesia, Tsunami mystery: clues from the tsunami waveform and the initial field survey data. Journal of Disaster Research, 13, 20181108.

Murty, T. S. (2003). Tsunami wave height dependence on landslide volume. Pure and Applied Geophysics, 160(10-11), 2147-2153. https://doi.org/10.1007/s00024-003-2423-z.

Omira, R., Dogan, G. G., Hidayat, R., Husrin, S., Prasetya, G., Annunziato, A., et al. (2019). The September 28th, 2018, Tsunami In Palu-Sulawesi, Indonesia: a Post-Event Field Survey. Pure and Applied Geophysics, 176(4), 1379-1395. https://doi. org/10.1007/s00024-019-02145-z.

PUSHIDROSAL-Naval Hydrographic and Oceanographic Center. (2016). Hidro-Oceanographic survey in Sunda Strait (in Bahasa, last accessed 20 February 2019) http://www.pushidrosal.id/ berita/1007/Dishidros-dan-Kemenko-Maritim-LaksanakanSurvei-Hidro-Oseanografi-di-Selat-Sunda/. 
PUSHIDROSAL-Naval Hydrographic and Oceanographic Center. (2019). Pushidrosal assesses bathymetric change and geomorphology of Anak Krakatau Volcano (in Bahasa, last accessed 20 March 2019 http://www.pushidrosal.id/berita/6344/PUSHID ROSAL-TELITI-PERUBAHAN-KONTUR-KEDALAMANDAN-GEOMORFOLOGI-GUNUNG-ANAK-KRAKATAU/).

Rabinovich, A. B. (1997). Spectral analysis of tsunami waves: separation of source and topography effects. Journal of Geophysical Research: Oceans, 102(C6), 12663-12676.

Rabinovich, A. B. (2010). Seiches and harbor oscillations. In: Handbook of coastal and ocean engineering (pp. 193-236).

Rabinovich, A. B., Lobkovsky, L. I., Fine, I. V., Thomson, R. E., Ivelskaya, T. N., \& Kulikov, E. A. (2008). Near-source observations and modeling of the Kuril Islands tsunamis of 15 November 2006 and 13 January 2007. Advances in Geosciences, 14, 105-116.
Rabinovich, A. B., Titov, V. V., Moore, C. W., \& Eblé, M. C. (2017). The 2004 Sumatra tsunami in the southeastern Pacific Ocean: new global insight from observations and modeling. Journal of Geophysical Research, 122(10), 7992-8019.

Shuto, N. (1987). The effectiveness and limit of tsunami control forest. Coastal Engineering Journal, 30(1), 143-153. https://doi. org/10.1080/05785634.1987.11924470.

UNESCO. (2014). International tsunami survey team (ITST) posttsunami survey field guide, 2nd ed. IOC Manuals and Guides No 37, Paris: UNESCO 2014 (English).

Welch, P. (1967). The use of fast Fourier transform for the estimation of power spectra: A method based on time averaging over short, modified periodograms. In IEEE Transactions Audio Electroacoustics, AE-15, 70-73.

https://doi.org/10.1016/j.oceaneng.2019.106733.

((Received May 2, 2019, revised October 28, 2019, accepted October 28, 2019, Published online November 21, 2019)) 